\title{
Flare Phenomenon in Advanced Colorectal Cancer: Cessation of Bevacizumab after Predefined Cycles of Therapy may not Affect Outcome
}

\author{
A. Ali BESEN ${ }^{1}$, Fatih KOSE ${ }^{1}$, Ahmet T. SUMBUL ${ }^{1}$, Nuriye OZDEMIR ${ }^{2}$, \\ Ozgur OZYILKAN', Nurullah ZENGIN², Huseyin ABALI ${ }^{3}$ \\ ${ }^{1}$ Baskent University Faculty of Medicine, Department of Medical Oncology, Adana \\ ${ }^{2}$ Ankara Numune Training and Research Hospital, Department of Medical Oncology, Ankara \\ ${ }^{3}$ Acrbadem University, Department of Medical Oncology, Adana, TURKEY
}

\begin{abstract}
Limited number of experimental and clinical studies showed rapid tumor regrowth after bevacizumab cessation in advanced colorectal cancer. We retrospectively evaluated rapid regrowth phenomenon in 105 patients those who were treated with the predefined number of chemotherapy cycles and grouped according to whether the chemotherapy regimen in the first line setting included bevacizumab (CT-Bev arm) or not (CT arm). Median age was 55 years old. Median overall and progression free survival times were 27 and 11 months, respectively. Rapid progression rates were $42 \%$ and $40 \%$ in CT arm and CT-Bev arm without no statistically significant difference ( $p=0.84)$. In CT arm, significantly more patients with stable disease (SD) progressed rapidly compared to patients with complete (CR) or partial response (PR) (53\% vs. $27 \%, p=0.04)$. This result was also similar in CT-Bev arm (48\% vs. $30 \%, p=0.27)$ but could not reach to the significant $p$-value. Overall survival 2, the time from the end of last dose of chemotherapy $+/$ - bevacizumab to death, was significantly shorter in both CT and CT-Bev arms for patients who showed SD compared to CR or PR (15 vs 38 months) ( $p<$ 0.001).Current study supports that withdrawal of bevacizumab after predefined treatment cycles may not have any adverse effect on patients' outcome of advanced CRC. This result is particularly acceptable for the patients who show CR or PR to the treatment. Keywords: Flare phenomenon, Colorectal cancer, Bevacizumab cessation, Chemotherapy, Rebound progression
\end{abstract}

ÖZET

İleri Evre Kolorektal Kanserli Hastalarda Alevlenme Fenomeni: Önceden Belirlenmiş Sayida Verilen Bevasizumabin Kesilmesi Sağkalimi Olumsuz Etkilemeyebilir

Sınırı sayıda deneysel ve klinik çalışmada ileri evre kolorektal kanserli hastada bevasizumabın kesilmesinin hızlı tümör büyümesine neden olduğu gösterilmiştir. Hızlı tümör büyümesi fenomenini birinci basamakta daha önceden belirlenmiş sayıda kemoterapi alan ve aldıkları kemoterapi rejiminin bevasizumab içerip içermemesine göre 2 gruba ayrın (KT-Bev veya KT) 105 kolorektal kanserli hastada değerlendirdik. Ortanca yaş 55 idi. Ortanca toplam ve progresyonsuz sağkalım süresi sırasıyla 27 ve 11 aydı. Hızlı progresyon oranı KT ve KT-Bev kolunda sırası ile \%42 ve \%40 idi ve aralarında istatistiksel fark yoktu ( $p=0.84)$. KT kolunda stabil hastalığı (SH) olanlar tam (TY) veya kısmi (KY) yanıt gösterenlere göre anlamlı olarak hızı progresyon gösterdiler (\%53 vs. \%27, $p=0.04)$. Bu sonuç KT-Bev kolunda benzer olmakla birlikte istatistiksel anlamllığa ulaşmadı (\%48 vs.\%30, $p=0.27$ ). Son kemoterapi +/- bevasizumab dozundan ölüme kadar geçen süre olarak tanımlanan toplam sağkalım 2 süesi (TS2) SD'de TY veya KY olanlara göre daha kısa idi (15 vs 38 ay: $p<0,001)$. Bu çalışma daha önceden belirlenmiş sayıda verilmiş olan bevasizumabın kesilmesinin ileri evre kolorektal kanserli hastalarda sağkalımı olumsuz etkilemeyebileceğini desteklemektedir. Bu özellikle tedaviye TY veya KY gösterenler için geçerlidir.

Anahtar Kelimeler: Alevlenme fenomeni, Kolorektal kanser, Bevasizumab kesilmesi, Kemoterapi, Rebound progresyon. 


\section{INTRODUCTION}

Angiogenesis, one of the ten cancer hallmarks, is necessary for the development of tumor beyond the certain volume, facilitates invasion, and metastases. ${ }^{1}$ VEGF (vascular endothelial growth factor) is a potent growth factor that has a central role in regulating tumor angiogenesis. ${ }^{2,3}$ It increases endothelial cell spurring, help the formation of the new vascular vessel, with a higher concentration around the tumor, leads to newly forming vessels to tumor tissue. ${ }^{3,4}$ Bevacizumab, a monoclonal antibody targeting VEGF molecule, significantly decrease VEGF concentration in the tumor microenvironment and exerts the anti-tumor effect by disturbing tumor nourishment. VEGF receptors are highly expressed in colon cancer. There is strong evidence supported by randomized phase studies that bevacizumab shows an improvement in response rate and survival rates in advanced colorectal cancer (CRC) ${ }^{5-8}$ Although, the positive impact of bevacizumab was on response parameters, the main effect of bevacizumab is cytostatic rather that cytotoxic. This comes with the concern of rapid tumor regrowth after discontinuation of bevacizumab.

The experimental study reported by Mancuso et.al. showed that interruption of anti-VEGF therapy resulted with fully tumor revascularization through the surviving pericytes and empty sleeves of vascular basement membrane in mice model in seven days. ${ }^{9}$ Beyond this experimental study, there is a small clinical study by Cacheux et.al. which showed rapid tumor regrowth occurred between the second and third month after cessation of bevacizumab. ${ }^{10}$ As far as we know there is no study addressing the impact of stopping bevacizumab on outcomes of advanced colorectal cancer for patients who do not progress on this therapy.

To evaluate this, we retrospectively analyzed nonprogressive advanced CRC patients treated with predefined cycles of chemotherapy with or without bevacizumab to show the effects of bevacizumab cessation on rapid regrowth phenomenon.

\section{PATIENTS AND METHOD}

Medical charts of 400 advanced colorectal carcinoma patients followed by the Department of Med- ical Oncology at Baskent University and Ankara Numune Research and Training Hospital between 2001 and 2010 were reviewed retrospectively. Due to local reimbursement issues, advanced CRC patients could be treated with bevacizumab plus chemotherapy in the first line setting during this period. 105 patients were suitable for the aim of the study. All patients were treated with chemotherapy plus bevacizumab or chemotherapy; at least, for two months with the proven clinical benefit $(\mathrm{CR}+\mathrm{PR}+\mathrm{SD})$ according to RECIST 1.1. The patients with treatment related unmanageable drug toxicity or intolerance were excluded, but dose reduction permitted according to CTCAE IV. All patients had histologically confirmed stage IV colon or rectum adenocarcinoma. Demographic and clinical characteristics of patients including age, localization of primary tumor (rectum vs colon), sequence of metastatic disease (metachronous vs synchronous metastasis), grade of tumor, type of chemotherapy in metastatic setting and prior adjuvant chemotherapy were recorded. Patients grouped according to whether the chemotherapy regimen administered in the first line setting included bevacizumab (CT-Bev arm) or not (CT arm).

\section{Chemotherapy Regimens}

In patients on CT-Bev arm, bevacizumab $(5 \mathrm{mg} /$ $\mathrm{kg}$, first dose over 90 minutes and after that over 30 minutes if tolerated well ) was administered only combined with standard FOLFIRI regimen (leucovorin (LV) $400 \mathrm{mg} / \mathrm{m}^{2}$ as a 2-hour infusion followed by irinotecan $180 \mathrm{mg} / \mathrm{m}^{2}$ given as a 90-minute infusion and then 5 fluorouracil (5-FU) 400 $\mathrm{mg} / \mathrm{m}^{2}$ iv bolus followed by $5-\mathrm{FU} 2400 \mathrm{mg} / \mathrm{m}^{2}$ administered as a 46-hour infusion every two weeks) due to reimbursement issues. FOLFIRI plus bevacizumab was given as predefined number of cycles (minimum four cycles and up to maximum $12 \mathrm{cy}$ cles). The remaining patients were treated with oxaliplatin based regimens which consisted of oxaliplatin $\left(100 \mathrm{mg} / \mathrm{m}^{2}\right.$ and $85 \mathrm{mg} / \mathrm{m}^{2}$ given as a 2-hour infusion as FOLFOX-6 and modified FOLFOX-4 respectively) plus 5-FU+LV as the same protocol that mentioned above or 5-FU plus LV alone or irinotecan combined with bolus 5-fluorouracil/leucovorin (Saltz regimen) or capecitabine as a single 


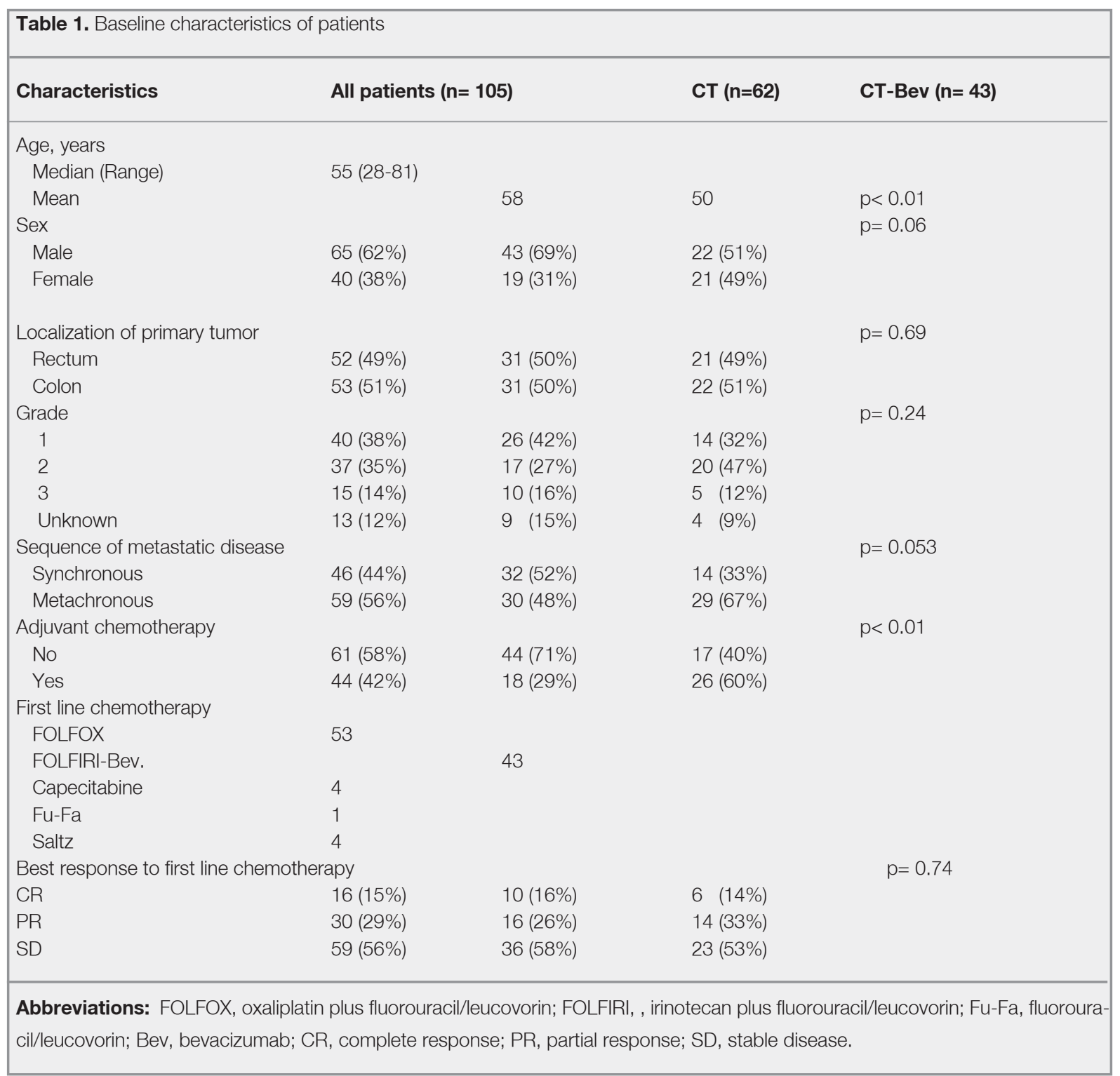

agent according to the physician's choice. Patients in CT arm were also given chemotherapy for predefined number of cycles (minimum four cycles and up to maximum 12 cycles) not until progression.

\section{Statistical Analysis}

All results were presented as rate for categorical values or mean and median for continuous variables. The primary objective of this study was to assess PFS 2 which is defined as the time from the last dose of bevacizumab (CT-Bev arm) or chemotherapy (CT arm) to the first documentation of pro- gression or death. PFS 1 was defined as the time from the initiation of first line chemotherapy to the initial sign of progression or death. OS1 was calculated from the first dose of chemotherapy administration to death and OS2 defined as the time from the end of last dose of chemotherapy +/- bevacizumab to death. In this study, rapid progression was defined as progression within three months after cessation of chemotherapy or chemotherapy plus bevacizumab. Survival curves were estimated according to the Kaplan-Meier method and log-rank tests were used for univariate statistical comparisons. Adjusted hazard ratios and 95\% confidence intervals (95\% CIs) were used for esti- 
mation. All data were analyzed using SPSS version 15.0 (SPSS Inc., Chicago, IL) and a p value of < 0.05 was considered statistically significant.

\section{RESULTS}

A total of 105 patients, $38 \%(n=40)$ were female and median age was 55 years old (range 28-81). Some of the patient and disease characteristics are summarized in Table 1. Rate of the primary tumor localization and grades did not show statistically significant difference between CT arm and CTBev arm ( $p>0.05$ for both). However, statistically analyses showed significant difference between two groups with regard to adjuvant chemotherapy (29\% vs $60 \%$ of the patients were given adjuvant chemotherapy in CT arm and CT-Bev arm respectively) and age (58 in CT arm vs 50 years old in CT-Bev arm) with $p$ values of $p<0.001$ and $p<$ 0.001 respectively. FOLFIRI was the only regimen combined with bevacizumab and FOLFOX was the main regimen in CT arm (85\% of patients).

The median PFS2 was 5.0 months (95\% CI, 3.56.4) for CT arm and 5.0 months (95\% CI, 3.6-6.3) for CT-Bev arm $(\mathrm{p}=0.33)$ (Figure 1). Univariate analyses failed to show statistically significant effect of primary tumor localization, tumor grade, the sequence of metastatic disease, ECOG PS, sex and administration of adjuvant chemotherapy on PFS2.

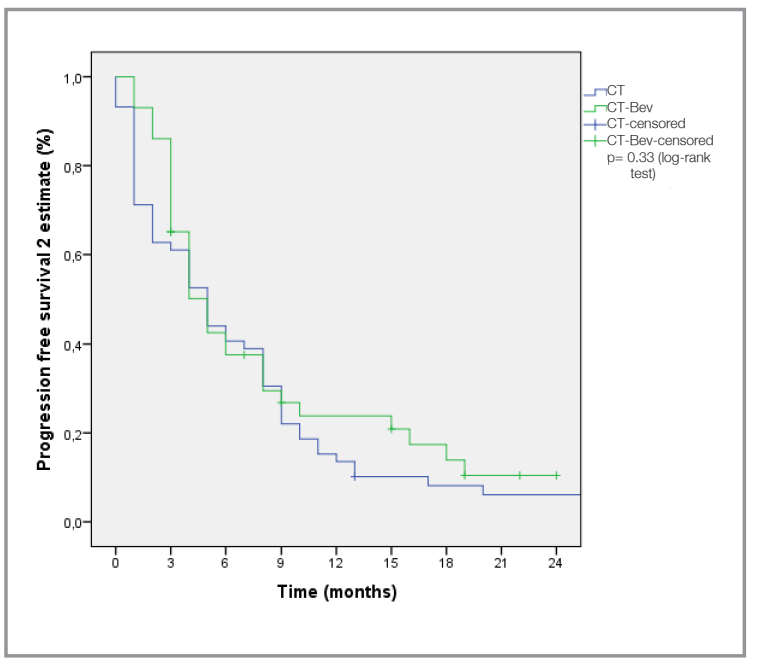

Figure 1. Kaplan-Meier estimate of progression free survival 2 according to treatment groups

PFS1 was 10.0 (95\% CI, 8.9-11.0) and 11.0 (95\% CI, 10.0-12.7) months for the CT arm and CT-Bev arm, respectively $(\mathrm{p}=0.24)$ (Table2). Univariate analyses failed to show the statistically significant effect of primary tumor localization, tumor grade, sequence of metastatic disease, ECOG PS, sex and administration of adjuvant chemotherapy on PFS1.

The median duration of OS1 for the entire cohort was 27.0 months (95\% CI, 21.6-32.3). KaplanMeier curve for OS1 is shown in Figure 2. The median OS1 was found as 27 and 28 months in CT arm and CT-Bev arm, respectively ( $\mathrm{p}>0.05$ ).

\begin{tabular}{|l|l|l|}
\hline Table 2. Definitions and median times of PFS1, PFS2, OS1 and OS2 according to the treatment groups. \\
\hline
\end{tabular}




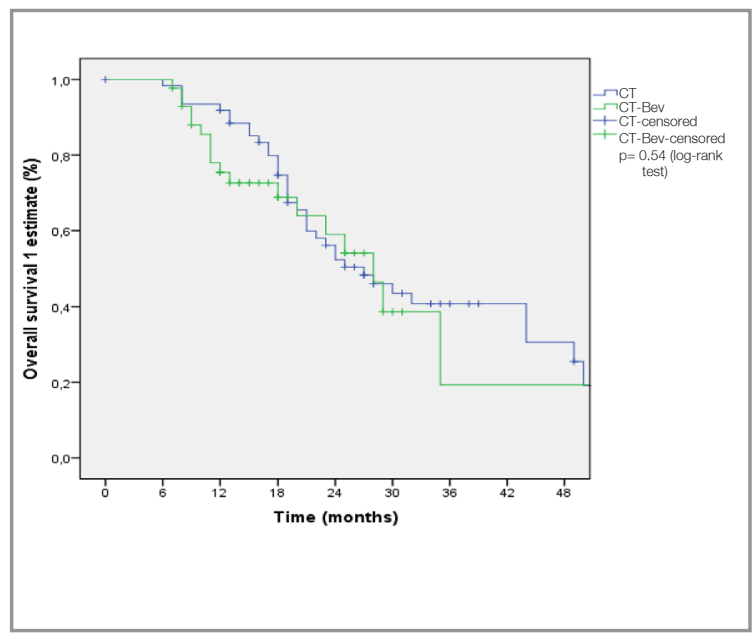

Figure 2. Kaplan-Meier estimate of overall survival

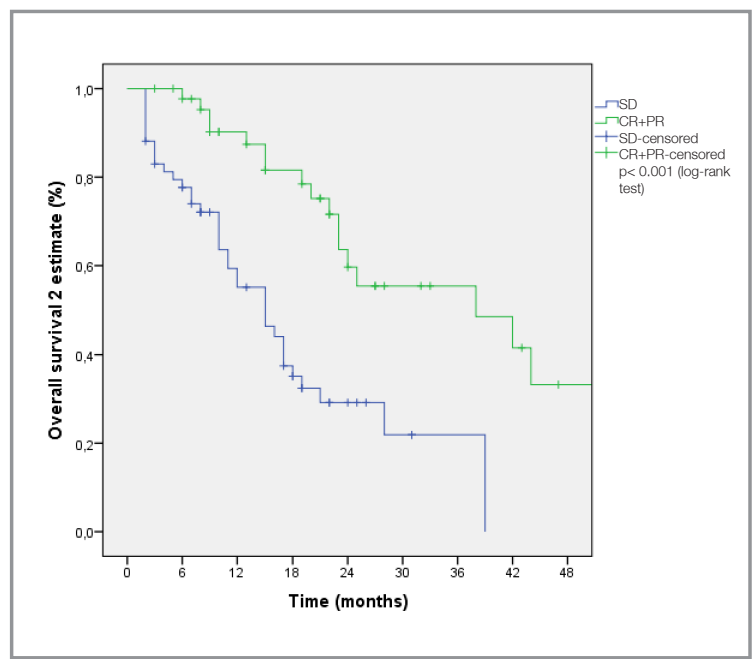

Figure 4. Kaplan-Meier estimate of overall survival 2 according to chemotherapy responses

The median OS2 was found 21.0 months for all patients $(95 \% \mathrm{CI}, 16.1-25.8)$ and was similar in CT arm and CT-Bev arm as shown in Figure 3. However, for patients with SD OS2 was significantly lower compared to patients who had CR or PR (15.0 vs 38.0 months) $(\mathrm{p}<0.001)$ (Figure 4)

Number of patients with rapid progression were found in 26 (42\%) in CT arm and 17 (40\%) in CTBev arm, there was no statistically significant difference $(\mathrm{p}=0.84)$.

According to the best first line chemotherapy response, number of patients with CR, PR and, SD

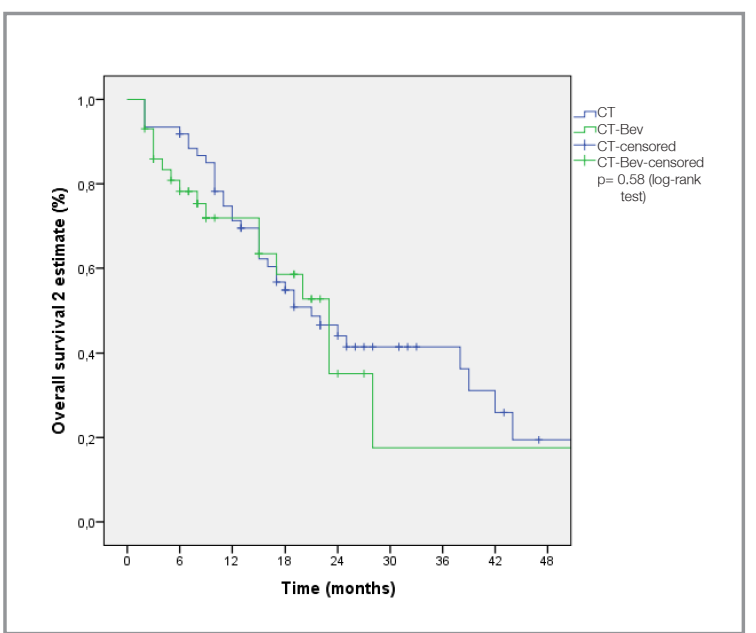

Figure 3. Kaplan-Meier estimate of overall survival 2 according to treatment groups

were found as $10(16 \%)$ vs. $6(14 \%), 16(26 \%)$ vs. $14(33 \%)$ and, $36(57 \%)$ vs $23(53 \%)$ for patients in CT arm and CT-Bev arm, respectively ( $\mathrm{p}>0.05$ for all).

In CT arm, significantly more patients with SD (19 of 36 patients) progressed rapidly compared to patients with CR or PR (7 of 26 patients) (53\% vs. $27 \%)(\mathrm{p}=0.04)$. In CT-Bev arm, although not reached to threshold of statistically significant value, rapid progression rate was also higher in patients with SD (48\% vs. $30 \%)(\mathrm{p}=0.23)$ when compared to patients with $\mathrm{CR}$ and PR.

\section{DISCUSSION}

The survival of advanced CRC has improved notably in the recent years by the contribution of novel biological drugs such as anti-epidermal growth factor and anti-VEGF antibodies to conventional chemotherapy. However, there is still a debate on the optimal combination and duration of chemotherapeutics and biological agents. The incorporation of anti-VEGF treatment into 5-fluorouracil based cytotoxic regimens is an option in the first and second line treatment for advanced CRC. Continuous administration of bevacizumab until progression or unacceptable toxicity is recommended by well accepted international guidelines. ${ }^{11-13}$ However, there are some significant issues; the first is the high cost especially in continuous administra- 
tion. The second is accelerated tumor progression after cessation of the anti-VEGF, bevacizumab in particular, which is endorsed by several preclinical and observational studies. ${ }^{9,10,14}$ The third issue is evidence supporting the continuation of bevacizumab beyond progression in the second-line. ${ }^{13}$ Therefore, defining a particular group of patients who can safely discontinue bevacizumab after proven tumor response is necessary and may help to solve these issues. To the best of our knowledge, this is the first study challenging cessation of bevacizumab after predefined treatment cycles in advanced $\mathrm{CRC}$.

To criticize, we mainly evaluated PFS2 and progression within three months of bevacizumab and/ or chemotherapy. We suppose that these two parameters were of particular importance in the evaluation of the rapid progression after bevacizumab therapy since they were not affected by the data of subsequent treatments. Our study results showed that median PFS2 was similar for both CT and CTBev arms. Likewise, the rate of rapidly progressed patients was not different in two groups (nearly $40 \%$ ). But, we found statistically significant correlation between OS2, type of response, and rapid progression rate.

Statistical analysis failed to show significant difference between CT and CT-Bev arms with regard to OS1 and OS2. Discontinuation of bevacizumab was not associated with decreased PFS or rapid tumor progression in advanced CRC patients. Although, OS1 and OS2 were not reduced in the subgroup of patients who had rapid progression, therapies in second and third line setting might explain this. Response to first-line chemotherapy showed the significant relation with primary outcomes (rapid progression rate and OS2) of this study. Rapid progression rate in CT arm was significantly higher in patients who showed SD compared to $\mathrm{CR}$ or PR, even though the higher rate of rapidly progressed patients in CT-Bev arm was not statistically significant.

OS2 in CT arm and CT-Bev arm was significantly shorter in patients who showed SD compared to CR or PR. Reduced survival rate of patients with SD was independent of discontinuation bevacizumab underlines the relevance of treatment response in advanced CRC.
There are at least two more studies in the literature which evaluated the effect of bevacizumab cessation in non-progressed advanced cancer patients. Miles et al. retrospectively evaluated five randomized, placebo-controlled phase III studies (colorectal, breast, renal and pancreatic cancer) to investigate whether premature discontinuation of bevacizumab was associated with accelerated tumor progression. The final analysis of these five trials showed that time from discontinuation of treatment as a result of adverse events to death was similar for bevacizumab and placebo groups. Interestingly, PFS2 (5 months) in our patients were comparable to that reported in NO 16966 study (4.5 months for XELOX/FOLFOX plus bevacizumab group) which included data of colorectal cancer patients for this pooled analysis. ${ }^{15}$

Similar conclusions were drawn from the retrospective study reported by Anderson et al. in glioblastoma multiforme patients who discontinued bevacizumab for reasons other than tumor progression and received bevacizumab for at least 6 months. ${ }^{16}$

The potential rebound effect of bevacizumab was also addressed in the adjuvant colon cancer setting. The National Surgical Adjuvant Breast and Bowel Project C-08 trial was designed to assess the value of adding bevacizumab to modified FOLFOX 6 in stage II and III colon cancer. In this trial, number of patients who experienced recurrence and survival of patients after recurrence did not differ in the bevacizumab and the control arms. ${ }^{17}$

The limitations of our study were retrospective design in limited number patients, some degree of heterogeneity between CT arm and -Bev about patient characteristics, and absence of RAS mutational analysis. The rate of patients with previous adjuvant chemotherapy was higher in CT-Bev arm, and higher age in CT arm at the time of diagnosis were the most important ones. Beside, RAS and BRAF mutational status might also influence the survival and response to chemotherapy.

In conclusion, the current study supports that in advanced CRC, cessation of bevacizumab after predefined treatment cycles may have no negative effect on patients' outcome. This result is particularly acceptable for the patients who show $\mathrm{CR}$ or PR to the treatment. 


\section{REFERENCES}

1. Hanahan D, Weinberg RA. Hallmarks of cancer: the next generation. Cell 144: 646-674, 2011

2. Folkman J. Roleof angiogenesis in tumor growth and metastasis. Semin Oncol 29: 15, 2002.

3. Hanahan D, Folkman J. Patterns and emerging mechanisms of the angiogenic switch during tumorigenesis. Cell 86: 353$364,1996$.

4. McMahon G. VEGF receptor signaling in tumor angiogenesis. Oncologist 5: 3-10, 2000.

5. Hurwitz H, Fehrenbacher L, Novotny W, et al. Bevacizumab plus irinotecan, fluorouracil, and leucovorin for metastatic colorectal cancer. N Engl J Med 350: 2335-2342, 2004.

6. Giantonio BJ, Catalano PJ, Meropol NJ, et al. Bevacizumab in combination with oxaliplatin, fluorouracil, and leucovorin (FOLFOX4) for previously treated metastatic colorectal cancer: results from the Eastern Cooperative Oncology Group Study E3200. J Clin Oncol 25: 1539-1544, 2007.

7. Sobrero A, Ackland S, Clarke S, et al. Phase IV study of bevacizumab in combination with infusional fluorouracil, leucovorin and irinotecan (FOLFIRI) in first-line metastatic colorectal cancer. Oncology 77: 113-119, 2009.

8. Grothey A, Sugrue MM, Purdie DM, et al. Bevacizumab beyond first progression is associated with prolonged overall survival in metastatic colorectal cancer: results from a large observational cohort study (BRiTE). J Clin Oncol 26: $5326-$ 5334, 2008.

9. Mancuso MR, Davis R, Norberg SM, et al. Rapid vascular regrowth in tumors after reversal of VEGF inhibition. J Clin Invest 116: 2610-2621, 2006.

10. Cacheux W, Boisserie T, Staudacher L, et al. Reversible tumor growth acceleration following bevacizumab interruption in metastatic colorectal cancer patients scheduled for surgery. Ann Oncol 19: 1659-1661, 2008.

11. Bennouna J, Sastre J, Arnold D, et al. Continuation of bevacizumab after first progression in metastatic colorectal cancer (ML18147): a randomised phase 3 trial. Lancet Oncol 14: 2937, 2013.

12. Simkens $\mathrm{LH}$, van Tinteren $\mathrm{H}$, May $\mathrm{A}$, et al. Maintenance treatment with capecitabine and bevacizumab in metastatic colorectal cancer (CAIRO3): a phase 3 randomised controlled trial of the Dutch Colorectal Cancer Group. Lancet 385: 18431852,2015

13. Hegewisch-Becker $S$, Graeven U, Lerchenmüller $C A$, et al. Maintenance strategies after first-line oxaliplatin plus fluoropyrimidine plus bevacizumab for patients with metastatic colorectal cancer (AIO 0207): a randomised, non-inferiority, open-label, phase 3 trial. Lancet Oncol 16: 1355-1369, 2015.

14. Zuniga RM, Torcuator $\mathrm{R}$, Jain $\mathrm{R}$, et al. Rebound tumour progression after the cessation of bevacizumab therapy in patients with recurrent high-grade glioma. J Neurooncol 99: 237-422, 2010.
15. Miles D, Harbeck N, Escudier B, et al. Disease course patterns after discontinuation of bevacizumab: pooled analysis of randomized phase III trials. J Clin Oncol 29: 83-88, 2011.

16. Anderson MD, Hamza MA, Hess KR, Puduvalli VK. Implications of bevacizumab discontinuation in adults with recurrent glioblastoma. Neuro Oncol 16: 823-828, 2014.

17. Allegra CJ, Yothers G, O'Connell MJ, et al. Phase III Trial Assesing Bevacizumab in Stages II and III Carcinoma of the CoIon: Results of NSABP Protocol C-08. J Clin Oncol 29: 11-16, 2011.

\section{Correspondence:}

Dr. Ahmet Taner SÜMBÜL

Bașkent Universitesi Tıp Fakültesi

Tıbbi Onkoloji Anabilim Dalı

Kıșla Yerleșkesi YÜREĞiR

ADANA / TURKEY

Tel: (+90-505) 6166338

Fax: (+90-322) 3444445

e-mail: drtanersu@yahoo.com 